\section{Plant Growth-promoting Rhizobacteria Mitigate Deleterious Effects of Salt Stress on Strawberry Plants (Fragaria $\times$ ananassa)}

\author{
Huseyin Karlidag \\ Department of Horticulture, Faculty of Agriculture, Inonu University, \\ Malatya, Turkey
}

Ertan Yildirim ${ }^{1}$

Department of Horticulture, Faculty of Agriculture, Atatürk University, Erzurum, Turkey

\author{
Metin Turan \\ Department of Genetic and Bioengineering, Yeditepe University, 34755 \\ Istanbul, Turkey \\ Mucahit Pehluvan \\ Department of Horticulture, Faculty of Agriculture, Igdir University, Igdir, \\ Turkey
}

\section{Figen Donmez}

Department of Plant Protection, Faculty of Agriculture, Igdir University, Igdir, Turkey

Additional index words. plant growth-promoting rhizobacteria, plant nutrient, salinity stress, strawberry

\begin{abstract}
The effect of selected plant growth-promoting rhizobacteria (PGPR) on the growth, chlorophyll content, nutrient element content, and yield of strawberry plants under natural field salinity conditions stress was investigated. Field experiments were conducted using a randomized complete block design with five PGPRs (Bacillus subtilis EY2, Bacillus atrophaeus EY6, Bacillus spharicus GC subgroup B EY30, Staphylococcus kloosii EY37, and Kocuria erythromyxa EY43) and a control (no PGPR) in 2009 and 2010. PGPR inoculations significantly increased the growth, chlorophyll content, nutrient element content, and yield of strawberry plants. PGPR treatments lowered electrolyte leakage of plants under saline conditions. The leaf relative water content (LRWC) of plants rose with bacterial inoculation. All nutrient element contents of leaves and roots investigated were significantly increased with PGPR inoculations with the exception of sodium (Na) and chlorine $(\mathrm{Cl})$. The highest efficiency to alleviate salinity stress on the yield and nutrient uptake of strawberry plants was obtained from EY43 ( $228 \mathrm{~g}$ per plant) and EY37 (225 g per plant) treatment and the yield increasing ratio of plants was $48 \%$ for EY43 and $46 \%$ for EY 37 compared with the control treatment (154 g per plant). The highest nitrogen $(\mathrm{N})$, potassium $(\mathrm{K})$, phosphorus $(\mathrm{P})$, calcium $(\mathrm{Ca})$, magnesium $(\mathrm{Mg})$, sulfur $(\mathrm{S})$, manganese $(\mathrm{Mn})$, copper $(\mathrm{Cu})$, and iron $(\mathrm{Fe})$ concentrations were obtained from EY43 and followed by E6, E37, and E30, and increasing ratio of leaves and root $\mathrm{N}$, $\mathrm{P}, \mathrm{K}, \mathrm{Ca}, \mathrm{Mg}, \mathrm{S}, \mathrm{Mn}, \mathrm{Cu}$, and Fe contents were $22 \%$ to $33 \%, 34 \%$ to $8.8 \%, 89 \%$ to $11 \%$, $11.0 \%$ to $7.2 \%, 5.1 \%$ to $6.2 \%, 97 \%$ to $65 \%, 120 \%$ to $140 \%, 300 \%$ to $15 \%$, and $111 \%$ to $\mathbf{9 . 0} \%$, respectively. The results of the study suggested that PGPR inoculations could alleviate the deleterious effects of salt stress conditions on the growth and yield of strawberry plants under salinity conditions.
\end{abstract}

Salinity is one of the most important stress factors limiting plant growth and productivity. Salinity stress conditions negatively affect nearly 100 million ha around the world

Received for publication 27 Dec. 2012. Accepted for publication 18 Mar. 2013.

We are grateful to Ataturk University for generous financial support.

${ }^{1}$ To whom reprint requests should be addressed; e-mail ertanyil@atauni.edu.tr.

(Ghassemi et al., 1995) and almost 1.5 million ha in Turkey (Dinc et al., 1993). High salt concentrations cause osmotic shock and ionic imbalance on plant cells (Zhu et al., 1997). Salt stress negatively affects plant physiology, both in the whole plant as well as at cellular levels, through osmotic and ionic stress. High salt concentrations in soil solution can negatively influence seed germination, growth, flowering, and fruit set, decreasing yield and the quality in crops (Arora et al., 2008).
Strawberry cultivation (with 250,000 t production) (FAO Food and Agriculture Organization, 2009) has great importance in the horticulture sector in Turkey. Small family farms of 0.05 to 0.5 ha provide almost all of this production. Strawberry plants are considered to be a salt-sensitive crop and it was reported that salt stress conditions negatively affected plant growth and yield (Karlidag et al., 2009; Yildirim et al., 2009).

Studies have been conducted to ameliorate the negative effect of salt stress conditions on growth and yield, most focusing on chemical amelioration. PGPR can be an alternative approach for mitigation of salt stress. Recently, PGPR has been used as an alternative biological approach. Salt-tolerant bacterial inoculants may be useful in developing strategies to facilitate plant growth in salinity conditions (Bacilio et al., 2004). The PGPRs have been reported to ameliorate the negative effect of salt stress on the plant growth of vegetable crops such as tomato (Mayak et al., 2004), eggplant (Bochow et al., 2001), squash (Yildirim et al., 2006), bean (Yildirim and Taylor, 2005), artichoke (Saleh et al., 2005), and radish (Yildirim et al., 2008). Karlidag et al. (2011a) have determined that PGPR root inoculations could mitigate of the deleterious effects of salinity conditions on plant growth of strawberry in pot experiments. However, no attempts have to date been made to study the effects of PGPR on growth, productivity, and ionic compositions in strawberry plants under natural saline field conditions. Therefore, this experiment focuses on the effect of the exogenous root application of five different PGPRs on the plant growth, some physiological variables, and the chemical content of strawberry plants under saline field conditions.

\section{Materials and Methods}

This study was conducted under field conditions at Ataturk University, Hamza Polat Vocational School, in Upper Coruh Valley (Ispir) in Turkey in 2009 and 2010. Ispir is located at latitude $40^{\circ} 29^{\prime} \mathrm{N}$ and longitude $41^{\circ} 01^{\prime} \mathrm{E}, 1200 \mathrm{~m}$ above sea level and had a total rainfall of $245 \mathrm{~mm}$ in 2009 and $310 \mathrm{~mm}$ in 2010 , and average air temperature of $19.1{ }^{\circ} \mathrm{C}$ in 2009 and $18.6{ }^{\circ} \mathrm{C}$ in 2010 during the growing period (April to September). The mean minimum and maximum air temperatures were 11 and $27^{\circ} \mathrm{C}$ in 2009 and 12 and $28^{\circ} \mathrm{C}$ in 2010 , respectively (April to September).

\section{Bacterial isolation, culture, and treatment}

From an initial set of 44 bacteria that were isolated from the rhizosphere of plants naturally grown in high salty soils in Upper Coruh Valley (latitude $40^{\circ} 29^{\prime} \mathrm{N}$, longitude $41^{\circ} 01^{\prime} \mathrm{E}$ ), Erzurum, Turkey. Five bacteria of them were selected for their ability to grow in a saline culture medium $[10 \%$ sodium chloride $(\mathrm{NaCl})]$. Bacillus subtilis EY2, Bacillus atrophaeus EY6, Bacillus spharicus GC subgroup B EY30, Staphylococcus kloosii EY37, and Kocuria erythromyxa EY43 (with MIS 
similarity index of $0.760,0.710,0.580,0.580$, and 0.600 , respectively, based on fatty acid methyl ester analysis using Sherlock Microbial Identification system and confirmed with Biolog) were selected as inoculants. For this experiment, the bacterial strains were grown on nutrient agar. A single colony was transferred to $250-\mathrm{mL}$ flasks containing nutrient broth and grown aerobically in flasks on a rotating shaker $(95 \mathrm{rpm})$ for $24 \mathrm{~h}$ at $27^{\circ} \mathrm{C}$. Inoculation of bacterial treatments was performed using a dipping method in which plant roots in celled trays were inoculated with the bacterial suspensions of the concentration of $10^{8}$ colony-forming units $/ \mathrm{mL}$ in sterile water for $\approx 30 \mathrm{~min}$ before planting. Control plants were dipped into sterile water. The bacterial strains were able to grow in $\mathrm{N}$-free basal medium indicating their $\mathrm{N}$-fixing potential. In the present study, the P-solubilizing activities of the five PGPRs were measured according to the qualitative methods (Mehta and Nautiyal, 2001) (Table 1).

\section{Growth conditions and plant materials}

Cold-stored bare-rooted strawberry plants with one well-developed crown of diameter 8 to $10 \mathrm{~mm}$ were planted in celled-trays containing peat $[\mathrm{pH}: 5.5$, electrical conductivity (EC): $0.25 \mathrm{dS} \cdot \mathrm{m}^{-1}, \mathrm{~N}: 3006.6 \mathrm{~kg} \cdot \mathrm{ha}^{-1}, \mathrm{P}_{2} \mathrm{O}_{5}$ : $6.6 \mathrm{~kg} \cdot \mathrm{ha}^{-1}, \mathrm{~K}_{2} \mathrm{O}: 8.8 \mathrm{~kg} \cdot \mathrm{ha}^{-1}$, organic matter: $2 \%$. Twenty days after well-rooted and inoculated strawberry crowns were planted in late August of 2008 for the 2009 experiment and in 2009 for the 2010 experiment. The soil physical and chemical properties of the experimental area are presented in Table 2 . At the beginning of each growing season, $160 \mathrm{~kg} \cdot \mathrm{ha}^{-1} \mathrm{~N}$ and $180 \mathrm{~kg} \mathrm{P}_{2} 0_{5} \mathrm{~kg} \cdot \mathrm{ha}^{-1}$ as ammonium nitrate and triple superphosphate, respectively, were applied in between the rows (Hochmuth and Albert, 1995). Electrical conductivities of experiment soil were determined during experiments. The EC ranged from $1.30 \mathrm{dS} \cdot \mathrm{m}^{-1}$ at the beginning of the experiment to $3.50 \mathrm{dS} \cdot \mathrm{m}^{-1}$ at the end of the experiment. EC was measured in saturation extracts according to Rhoades (1996). Strawberry plots consisted of six rows spaced $30 \mathrm{~cm}$ apart and were $3 \mathrm{~m}$ in length with $30 \mathrm{~cm}$ within-row spacing. There were 18 plots. Plants were irrigated with natural saline water as furrows. The EC of the water was $3.16 \mathrm{dS} \cdot \mathrm{m}^{-1}$.

Table 1. Some biochemical characteristics of the bacterial strains tested.

\begin{tabular}{lcccc}
\hline Bacterial strain & Gram stain & Catalase & P solubilization & $\begin{array}{c}\text { Growth in nitrogen-free } \\
\text { basal medium }\end{array}$ \\
\hline Bacillus subtilis EY2 & + & + & - & + \\
Bacillus atrophaeus EY6 & + & + & - & + \\
Bacillus spharicus EY30 & + & + & + & + \\
Staphylococcus kloosii EY37 & + & + & + & + \\
Kocuria erythromyxa EY43 & + & + & + & + \\
\hline
\end{tabular}

Table 2. The soil some physical and chemical properties of experimental area.

\begin{tabular}{|c|c|c|c|c|c|c|c|c|c|c|c|}
\hline Sand & Silt & Clay & OM & $\mathrm{CaCO}_{3}$ & \multirow[b]{2}{*}{$\mathrm{pH}^{* *}$} & $\mathrm{~N}$ & $\mathrm{P}$ & $\mathrm{Ca}$ & $\mathrm{Mg}$ & $\mathrm{K}$ & $\mathrm{Na}$ \\
\hline & & $(\%)$ & & & & & $\left.\mathrm{g}^{-1}\right)$ & \multicolumn{4}{|c|}{$\left(\right.$ me $\left.100 \mathrm{~g}^{-1}\right)$} \\
\hline 31.3 & 21.5 & 47.2 & 0.95 & 5.42 & 7.5 & 17.3 & 10.13 & 13.24 & 5.32 & 1.30 & 0.5 \\
\hline
\end{tabular}

$\mathrm{OM}=$ organic matter; $\mathrm{pH}^{* *}=$ soil/water ratio $(1: 2.5 \mathrm{~s} / \mathrm{w})$.

There were no insecticide and fungicide treatments in either experiment. Weeds were kept under control by hand-weeding. In both years, regular cultural practices were applied uniformly through all plots.

\section{Chlorophyll measurements (SPAD readings)}

A portable chlorophyll meter (SPAD-502; Konica Minolta Sensing, Inc., Japan) was used to measure the leaf greenness of the strawberry plants. The SPAD-502 chlorophyll meter can estimate the total chlorophyll amounts in leaves of a variety of species with a high degree of accuracy, which is a nondestructive method (Neufeld et al., 2006). For each plant, measurements were taken at four locations on each leaf, two on each side of the midrib on all fully expanded leaves, and then averaged (Khan et al., 2003).

\section{Measurement of electrolyte leakage membrane permeability)}

For measurement of electrolyte leakage, 10 leaf discs (10 $\mathrm{mm}$ in diameter) from the young fully expanded leaves from two plants per replicate were placed in 50-mL glass vials insed with distilled water to remove the electrolytes released during leaf disc exciion. Vials were then filled with $30 \mathrm{~mL}$ of water and allowed to stand in the dark for $24 \mathrm{~h}$ at room temperature. The EC (EC1) of the bathing solution was determined at the end of the incubation period. Vials were heated in a temperature-controlled water bath at $95^{\circ} \mathrm{C}$ for $20 \mathrm{~min}$ and then cooled to room temperature and the $\mathrm{EC}$ (EC2) was measured. Electrolyte leakage was calculated as a percentage of EC1/EC2 (Shi et al., 2006).

\section{Leaf relative water content}

LRWC is a useful measure of the physiological water status of plants (Gonzalez and Gonzalez-Vilar, 2001). Two leaves were collected from the young fully expanded leaves of two plants per replicate. Individual leaves were first detached from the stem and then weighed to determine the fresh weight ). To determine the turgid weight (TW), leaves were floated in distilled water inside a closed petri dish. Leaf samples were weighed periodically after gently wiping the water from the leaf surface with tissue paper until a steady state was achieved. At the end of the imbibition period, leaf samples were placed in a preheated oven at $80^{\circ} \mathrm{C}$ for $48 \mathrm{~h}$ to determine the dry weight (DW). Values of FW, TW, and DW were used to calculate LRWC using the equation subsequently (Kaya et al., 2003):

$$
\begin{aligned}
\operatorname{LRWC}(\%)= & {[(\mathrm{FW}-\mathrm{DW}) /(\mathrm{TW}-\mathrm{DW})] } \\
& \times 100
\end{aligned}
$$

\section{Growth and yield parameters}

Harvesting was performed from July to September for both experiment years. Marketable strawberry fruits were harvested when they had reached full maturity. Ten plants from each replicate were harvested, and data on plant growth variables such as shoot FW, root FW, shoot DW, and root DW per plant were determined. The plant material for dry weight was dried at $70{ }^{\circ} \mathrm{C}$ for $48 \mathrm{~h}$.

\section{Mineral analysis}

Soil analysis. Soil samples were air-dried, crushed, and passed through a 2-mm sieve before chemical analysis. Soil texture was determined according to Gee and Bauder (1986). The Kjeldahl method (Bremner, 1996) was used to determine total N, whereas plant-available $\mathrm{P}$ was determined by using the sodium bicarbonate method of Olsen et al. (1954). EC was measured in saturation extracts according to Rhoades (1996). Soil $\mathrm{pH}$ was determined in 1:2.5 extracts, and calcium carbonate concentrations were determined according to McLean (1982). Soil organic matter was determined using the Smith-Weldon method according to Nelson and Sommers (1982). Ammonium acetate buffered at pH 7 (Thomas, 1982) was used to determine exchangeable $(\mathrm{K}, \mathrm{Ca}, \mathrm{Mg}, \mathrm{Na})$ cations. After extraction methods, $\mathrm{P}, \mathrm{K}, \mathrm{Ca}$, $\mathrm{Mg}$, and $\mathrm{Na}$ were determined using an inductively coupled plasma spectrophotometer (Optima 2100 DV, ICP/OES; Perkin-Elmer, Shelton, CT).

Plant analysis. Plant samples were ovendried at $68{ }^{\circ} \mathrm{C}$ for $48 \mathrm{~h}$ and ground to pass a 1-mm sieve. The Kjeldahl method and a Vapodest 10 Rapid Kjeldahl Distillation Unit (Gerhardt, Konigswinter, Germany) were used to determine the total $\mathrm{N}$ (Bremner, 1996). Macro- $(\mathrm{P}, \mathrm{K}, \mathrm{S}, \mathrm{Ca} \mathrm{Mg}$, and $\mathrm{Na})$ and microelements (Fe, $\mathrm{Mn}, \mathrm{Zn}$, and $\mathrm{Cu}$ ) were determined after wet digestion of dried and ground subsamples using a $\mathrm{HNO}_{3}-\mathrm{H}_{2} \mathrm{O}_{2}$ acid mixture $(2: 3 \mathrm{v} / \mathrm{v})$ with three steps [the first step: $145^{\circ} \mathrm{C}, 75 \%$ radiofrequency (RF), $5 \mathrm{~min}$; the second step: $180^{\circ} \mathrm{C}, 90 \% \mathrm{RF}, 10 \mathrm{~min}$; and the third step: $100{ }^{\circ} \mathrm{C}, 40 \% \mathrm{RF}, 10 \mathrm{~min}$ ) in a microwave (Bergof Speedwave Microwave Digestion Equipment MWS-2). Tissue P, K, S, $\mathrm{Ca}, \mathrm{Mg}, \mathrm{Fe}, \mathrm{Mn}, \mathrm{Zn}$, and $\mathrm{Cu}$ were determined using an inductively coupled plasma spectrophotometer (Perkin-Elmer) (Mertens, 2005a, 2005b).

\section{Statistical analysis}

The study was conducted using randomized complete block design with five PGPR treatments: no application (control), EY2, 
Table 3. Effects of PGPR application on plant growth, yield, membrane permeability, chlorophyll content, and LRWC of strawberry.

\begin{tabular}{|c|c|c|c|c|c|c|}
\hline & Control & EY2 & EY6 & EY30 & EY37 & EY43 \\
\hline Yield per plant (g) & $154 \pm 8 \mathrm{~d}^{z}$ & $186 \pm 11 \mathrm{c}$ & $205 \pm 3 b$ & $215 \pm 12 \mathrm{ab}$ & $225 \pm 5 \mathrm{a}$ & $228 \pm 10 a$ \\
\hline Shoot dry weight (g) & $32.12 \pm 3.4 \mathrm{c}$ & $36.33 \pm 1.1 \mathrm{~b}$ & $37.05 \pm 0.5 \mathrm{ab}$ & $39.35 \pm 1.3 \mathrm{a}$ & $37.66 \pm 0.2 \mathrm{a}$ & $38.21 \pm 0.6 \mathrm{a}$ \\
\hline Root fresh weight (g) & $18.67 \pm 0.3 \mathrm{c}$ & $20.10 \pm 1.3 b$ & $19.87 \pm 1.2 \mathrm{bc}$ & $20.53 \pm 1.5 b$ & $23.63 \pm 1.2 \mathrm{a}$ & $22.43 \pm 3.1 \mathrm{ab}$ \\
\hline Chlorophyll content & $36.71 \pm 0.1 \mathrm{~b}$ & $38.94 \pm 0.0 \mathrm{a}$ & $39.95 \pm 0.2 \mathrm{a}$ & $39.31 \pm 0.1 \mathrm{a}$ & $38.99 \pm 0.0 \mathrm{a}$ & $39.26 \pm 0.2 \mathrm{a}$ \\
\hline Membrane permeability (\%) & $42.66 \pm 2.1 \mathrm{a}$ & $43.22 \pm 2.4 \mathrm{a}$ & $37.68 \pm 1.8 \mathrm{~b}$ & $36.40 \pm 2.2 \mathrm{~b}$ & $38.36 \pm 1.6 \mathrm{~b}$ & $33.79 \pm 1.1 \mathrm{c}$ \\
\hline LRWC (\%) & $69.07 \pm 2.8 \mathrm{c}$ & $71.83 \pm 3.4 \mathrm{c}$ & $85.15 \pm 2.2 \mathrm{a}$ & $83.77 \pm 1.1 \mathrm{a}$ & $81.99 \pm 0.5 \mathrm{~b}$ & $82.40 \pm 5.8 \mathrm{ab}$ \\
\hline
\end{tabular}

${ }^{2}$ Mean values in lines followed by a different letters differ significantly.

PGPR = plant growth-promoting rhizobacteria; $\mathrm{LRWC}=$ leaf relative water content .

EY6, EY30, EY37, or EY43 and three replicates per treatment. All data in the present study were subjected to analysis of variance (ANOVA) using SPSS 18 (PASW Statistics 18) (SPSS Inc., 2010). Data were subjected to ANOVA to compare the effects of PGPR treatments. The differences between the means were compared using the Duncan test $(P<5 \%)$. Because there were no statistical differences between years, the data were pooled.

\section{Results and Discussion}

The results of the study introduced that yield per plant and growth were significantly increased by bacterial applications under salinity stress conditions and PGPR application could alleviate the deleterious effect of salt stress on the growth and yield of strawberry plants under natural salinity field conditions. Root FW, root DW, shoot FW, shoot DW, and SPAD readings in strawberry leaves were significantly increased by PGPR. Bacterial inoculations improved the growth parameters of strawberry plants compared with the non-inoculated control under salt stress. The greatest root FW and shoot FW values were obtained from EY37, whereas the greatest root DW and shoot DW were determined in EY43 treatment.

The highest amount of chlorophyll (SPAD readings) was obtained from EY6. Previous studies have shown that salinity conditions reduced the leaf number, leaf area, shoot FW and DW, chlorophyll content, and yield of strawberry (Karlidag et al., 2009, 2011b; Pirlak and Esitken, 2004; Yildirim et al., 2009). Negative effects of salinity on growth have been attributed to reduced water absorption resulting from the osmotic effect and photosynthesis ratio, sequestered salt interfering with cell function, ionic imbalance, and disorders in many metabolic activities (Kumar et al., 2005; Munns, 1993).

The present study demonstrates that PGPR inoculations alleviated the deleterious effects of salt stress on growth and yield of strawberry plants. In particular, EY37 and EY43 inoculations gave the highest values in terms of growth parameters and yield (Table 3). Similarly Yildirim et al. (2008) suggested that EY37 and EY43 inoculations could offer an alternative approach to alleviate the moderately salt-sensitive radish production problems in arid soil caused by high salinity. Our findings are concordant with previous studies showing that PGPR inoculations may stimulate
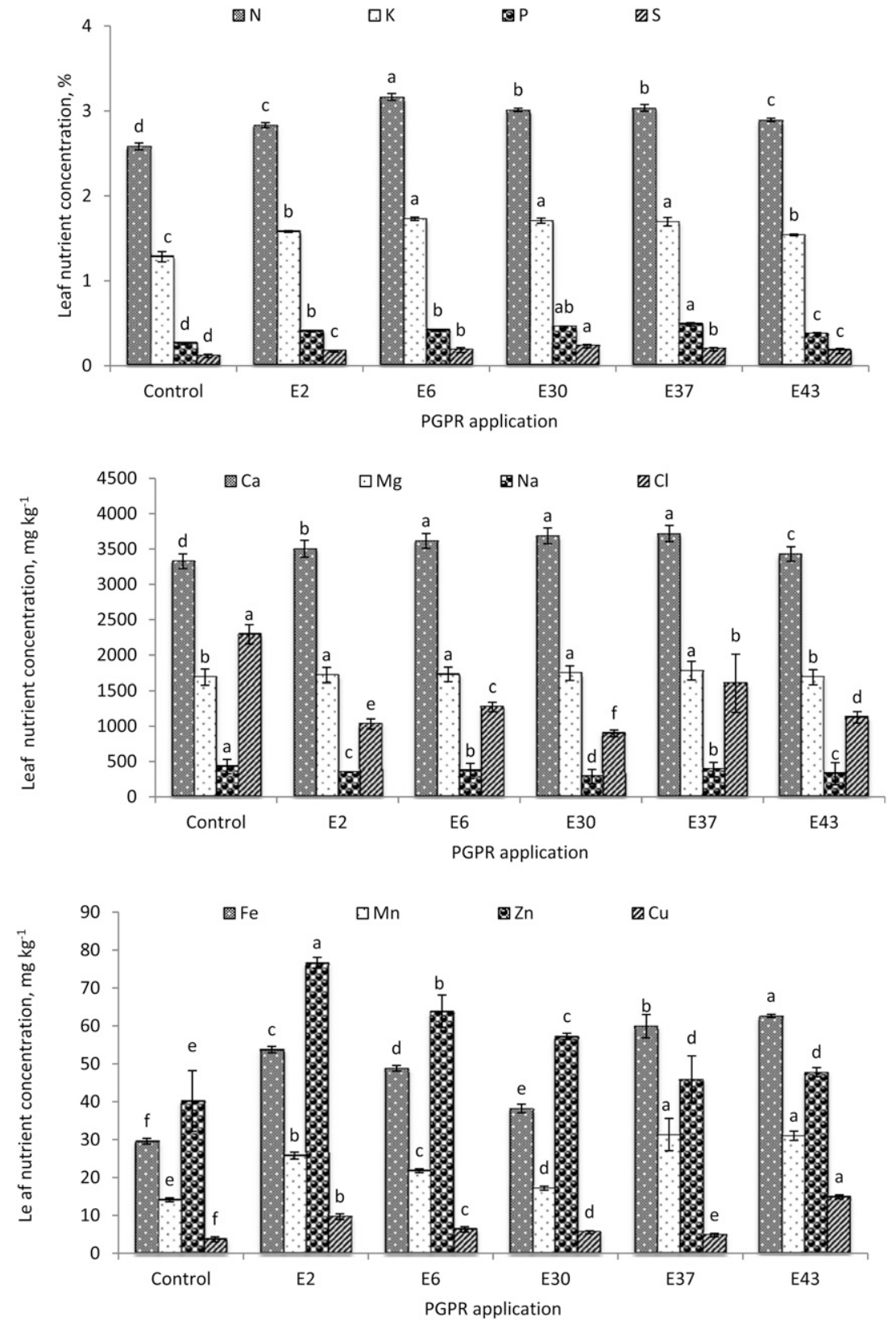

Fig. 1. Effects of plant growth-promoting rhizobacteria (PGPR) applications on plant nutrient element concentration of strawberry leaf under salinity conditions. Different letters on top of bars indicate differences (Duncan test, $P<0.05)$. Data are reported as means $(\mathrm{n}=3)$. Vertical bars indicate the mean \pm SE.

the yield and growth of different plant species under saline conditions (Barassi et al., 2006; Yildirim et al., 2006, 2011). PGPR inoculations elevated the chlorophyll reading values compared with the control. These findings are similar to those of Yildirim et al. (2008) who found that PGPR increased the chlorophyll reading values of radish leaves under salt stress. 

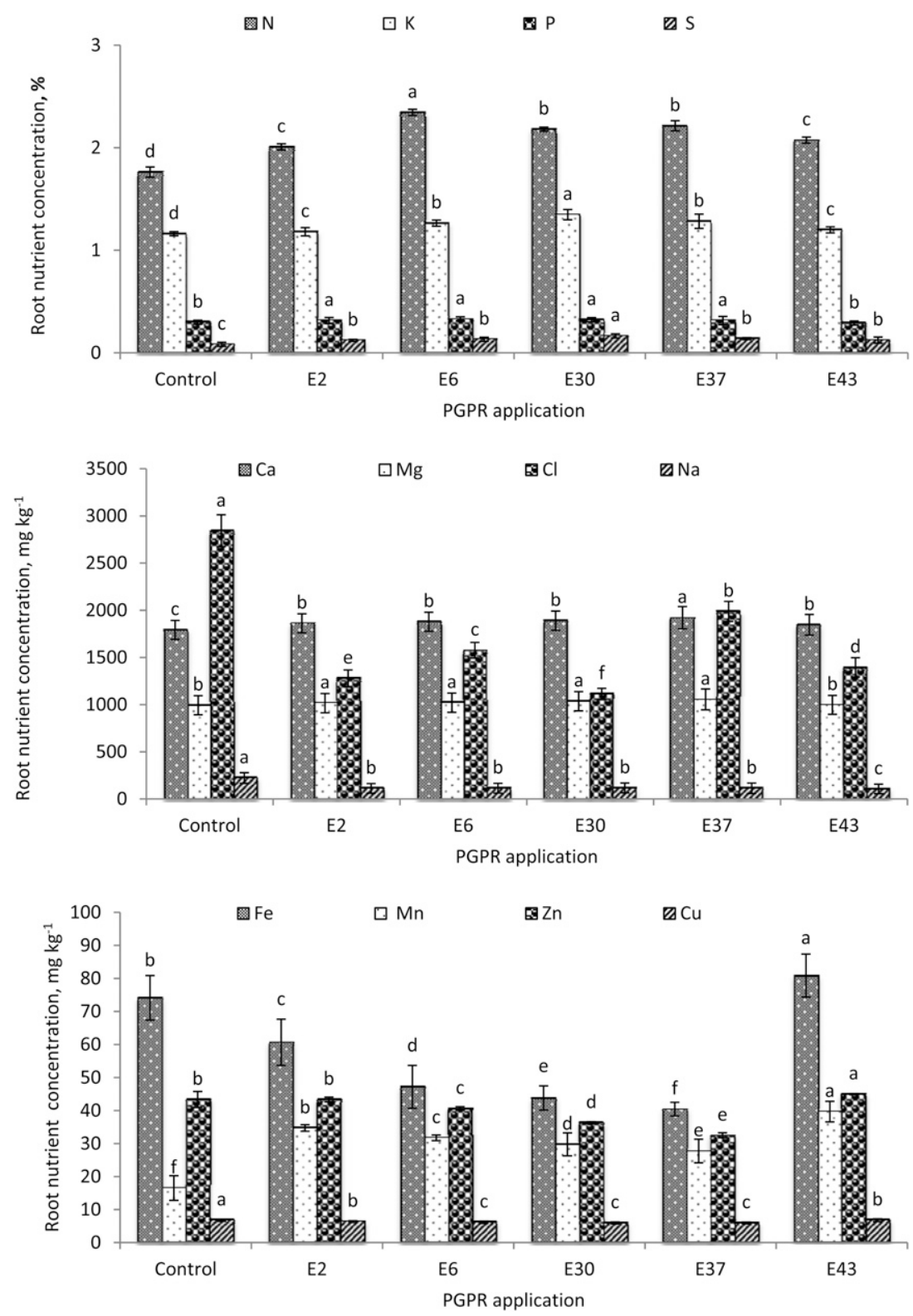

Fig. 2. Effects of plant growth-promoting rhizobacteria (PGPR) applications on plant nutrient element concentration of strawberry root under salinity conditions. Different letters on top of bars indicate differences (Duncan test, $P<0.05)$. Data are reported as means $(\mathrm{n}=3)$. Vertical bars indicate the mean \pm SE.

The positive effects of PGPR treatments on the yield and growth of plants can be attributed to the production of phytohormones such as indole-3-acetic acid and cytokinins, N2-fixation ability, phosphatesolubilizing capacity, and antimicrobial substance production. Organic acid, amino acid, enzyme, and hormone production of PGPR such as Bacillus megaterium (M3), Pantoea agglomerans (RK-92), Bacillus megaterium (Tv-17C), Bacillus megaterium (Tv-3D), Bacillus megaterium (Tv-87A), Hafnia alvei (Tv-34A), Bacillus megaterium (Tv-60D), Pseudomonas flourescens (FDG-37), Bacillus megaterium (KBA-10), and Bacillus megaterium (TV-91C) were determined (Gunes et al., 2013). PGPRs could help the growth of plants by mitigating deleterious effects of salinity conditions by promoting the accumulation of proline and glutamate (Bashan and Holguin, 1998). The promoting effects of PGPR under salinity conditions can be also attributed to control 1-aminocyclopropane-1carboxylate, inhibiting root growth by ethylene levels or blocking ethylene biosynthesis in plants, thus promoting root growth and helping to alleviate the negative effects of the salinity stress conditions (Mayak et al., 2004).

In the study, PGPR-treated strawberry plants had less membrane permeability compared with the control plants. It was suggested that PGPR can stimulate a PGPR-mediated induced systemic resistance and promote accumulation of the signaling molecules of salicylic acid and jasmonate. These molecules have been suggested to modulate plant responses to abiotic stress conditions (Pieterse et al., 2003).
Bacterial inoculations significantly $(P<$ 0.05) increased LRWC, which is a useful measure of the physiological water status of plants. EY6, EY30, and EY43 had greater LRWC values than the others (Table 3). Increased LRWC by PGPR have been reported for radish (Yildirim et al., 2008), lettuce (Yildirim et al., 2011), and strawberry (Karlidag et al., 2011a) grown under salt stress. Mayak et al. (2004) reported that PGPR could facilitate the rooting and growth of plants grown under salt stress by improving the water use efficiency.

Previous studies have reported that salinity conditions drastically decreased the plant nutrient element content of the leaves and roots of strawberry plants with the exception of $\mathrm{Na}$ and $\mathrm{Cl}$, which increased under salt stress (Karlidag et al., 2011b; Yildirim et al., 2009). However, the results of the study showed that PGPR inoculations elevated the macro- and micromineral content of the strawberry leaf and root compared with the non-inoculated plants under salinity conditions (Figs. 1 and 2). The highest N, K, P, Ca, $\mathrm{Mg}, \mathrm{S}, \mathrm{Mn}, \mathrm{Cu}$, and $\mathrm{Fe}$ concentrations were obtained from EY43 followed by E6, E37, and E30 and increasing ratio of leaves and root $\mathrm{N}, \mathrm{P}, \mathrm{K}, \mathrm{Ca}, \mathrm{Mg}, \mathrm{S}, \mathrm{Mn}, \mathrm{Cu}$, and $\mathrm{Fe}$ contents were $22 \%$ to $33 \%, 34 \%$ to $8.8 \%$, $89 \%$ to $11 \%, 11.0 \%$ to $7.2 \%, 5.1 \%$ to $6.2 \%$, $97 \%$ to $65 \%, 120 \%$ to $140 \%, 300 \%$ to $15 \%$, and $111 \%$ to $9.0 \%$, respectively. Conversely, bacterial inoculation significantly $(P<0.05)$ decreased the $\mathrm{Na}$ and $\mathrm{Cl}$ content of the leaf and root of strawberry plants. Similarly, previous studies proved that PGPR applications increased $\mathrm{N}, \mathrm{P}, \mathrm{K}, \mathrm{S}, \mathrm{Ca}, \mathrm{Mg}, \mathrm{Fe}, \mathrm{Mn}$, etc., whereas they decreased the $\mathrm{Na}$ and $\mathrm{Cl}$ contents in different plants under salt stress (Mayak et al., 2004; Yildirim et al., 2006, 2008). The higher total $\mathrm{N}$ and $\mathrm{P}$ content of the strawberry leaf and root could be aroused by $\mathrm{N}$ fixation and $\mathrm{P}$ solubilization of PGPR (Table 1). PGPRs that are phosphatesolubilizing and N2-fixing can improve the $\mathrm{N}$ and $\mathrm{P}$ nutrition of plants. Furthermore, PGPR could increase the mineral element uptake by stimulating root formation and growth (Yildirim et al., 2011). Ashraf et al. (2004) suggested that exopolisaccaride-producing PGPR restricted $\mathrm{Na}$ influx into roots. PGPR inoculations have been reported to reduce the $\mathrm{Na}$ content of squash and/or increase $\mathrm{K}$ and $\mathrm{Ca}$ contents compared with the non-inoculated plants.

In conclusion, the present study suggests that PGPR inoculations could alleviate the deleterious effects of salinity conditions in soil by increasing plant growth, chlorophyll content, and altering mineral uptake, therefore enhancing salt tolerance in strawberry plants.

\section{Literature Cited}

Arora, N., R. Bhardwaj, P. Sharma, and H.K. Arora. 2008. Effects of 28-homobrassinolide on growth, lipid peroxidation and antioxidative enzyme activities in seedlings of Zea mays L. under salinity stress. Acta Physiol. Plant. 30:833839. 
Ashraf, M., S. Hasnain, O. Berge, and T. Mahmood. 2004. Inoculating wheat seedling with exopolysaccharide-producing bacteria restricts sodium uptake and stimulates plant growth under salt stress. Biol. Fertil. Soils 40:157-162.

Bacilio, M., H. Rodrigeuez, M. Moreno, J. Harnendez, and Y. Bashan. 2004. Mitigation of salt stress in wheat seedlings by a gfp-tagged Azospirillum lipoferum. Biol. Fertil. Soils 40:188-193.

Barassi, C.A., G. Ayrault, C.M. Creus, R.J. Sueldo, and M.T. Sobrero. 2006. Seed inoculation with Azospirillum mitigates $\mathrm{NaCl}$ effects on lettuce. Sci. Hort. 109:8-14.

Bashan, Y. and G. Holguin. 1998. Proposal for the division of plant growth-promoting rhizobacteria into two classifications: Biocontrol PGPB (plant growth-promoting bacteria) and PGPB. Soil Biol. Biochem. 30:1225-1228.

Bochow, H., S.F. El-Sayed, H. Junge, A. Stauropoulou, and G. Schmieeknecht. 2001. Use of Bacillus substilis as biocontrol agent. IV. Salt-stress tolerance induction by Bacillus substilis FZB24 seed application in tropical vegetable field crops, and its mode action. J. Plant Dis. Prot. 108:21-30.

Bremner, J.M. 1996. Nitrogen-total, p. 1085-1121. In: Bartels, J.M. and J.M. Bigham (eds.). Methods of soil analysis, Part 3: Chemical methods. Soil Science Society of America and the American Society of Agronomy, Madison, WI.

Dinc, U., S. Senol, S. Kapur, O. Atalay, and C. Cangir. 1993. Soils of Turkey. Cukurova University, Adana, Turkey [in Turkish].

FAO Food and Agriculture Organization. 2009. FAOSTAT - agricultural statistics.

Gee, G.W. and J.W. Bauder. 1986. Particle-size analysis, p. 383-441. In: Klute, A. (ed.). Methods of soil analysis. Part 1. Physical and mineralogical methods. Soil Science Society of America and the American Society of Agronomy, Madison, WI.

Ghassemi, F., A.J. Jakeman, and H.A. Nix. 1995. Salinization of land and water resources. CAB International, Wallingford, UK.

Gonzalez, L. and M. Gonzalez-Vilar. 2001. Determination of relative water content, p. 207212. In: Reigosa, M.J. (ed.). Handbook of plant ecophysiology techniques. Kluwer Academic Publishers, Dordrecht, The Netherlands.

Gunes, A., K. Karagoz, M. Turan, R. Kotan, E. Yildirim, R. Cakmakci, and F. Sahın. 2013. Fertilizer efficiency of some plant growth promoting rhizobacteria for plant growth. J. Plant Nutr. (in press).

Hochmuth, G. and E. Albert. 1995. Fertilization of strawberries in Florida. Fla. Coop. Ext. Serv. Circ. 1152. University of Florida, FL.

Karlidag, H., A. Esitken, E. Yildirim, M.F. Donmez, and M. Turan. 2011a. Effects of plant growth promoting bacteria (PGPB) on yield, growth, leaf water content, membrane permeability and ionic composition of strawberry under saline conditions. J. Plant Nutr. 34:34-45.

Karlidag, H., E. Yildirim, and M. Turan. 2011b. Role of 24-epibrassinolide in mitigating the adverse effects of salt stress on stomatal conductance, membrane permeability, and leaf water content, ionic composition in salt stressed strawberry (Fragaria $\times$ ananassa). Sci. Hort. 130:133-140.

Karlidag, H., E. Yildirim, and M. Turan. 2009. Salicylic acid ameliorate the adverse effect of salt stress on strawberry. Sci. Agr. 66:180-187.

Kaya, C., H. Kirnak, D. Higgs, and K. Saltati. 2003. Supplementary calcium enhances plant growth and fruit yield in strawberry cultivars grown at high $(\mathrm{NaCl})$ salinity. Sci. Hort. 26:807-820.

Khan, W., B. Prithiviraj, and D.L. Smith. 2003 Photosynthetic responses of corn and soybean to foliar application of salicylates. J. Plant Physiol. 160:485-492.

Kumar, R., V. Goyal, and M.S. Kuhad. 2005. Influence of fertility-salinity interactions on growth, water status and yield of Indian mustard (Brassica juncea). Indian J. Plant Physi. 10:139-144.

Mayak, S., T. Tirosh, and B.R. Glick. 2004. Plant growth-promoting bacteria that confer resistance to water stress in tomatoes and pepper. Plant Sci. 166:525-530.

McLean, E.O. 1982. Soil pH and lime requirement, p. 199-224 In: Methods of soil analysis. Part II. Chemical and microbiological properties. ASA, Madison, WI.

Mehta, S. and C.S. Nautiyal. 2001. An efficient method for qualitative screening of phosphatesolubilizing bacteria. Curr. Microbiol. 43:5156.

Mertens, D. 2005a. AOAC official method 922.02. Plants preparation of laboratory sample, p. 1-2. In: Horwitz, W. and G.W. Latimer (eds.). Official methods of analysis. 18th Ed. AOACInternational, Gaitherburg, MD.

Mertens, D. 2005b. AOAC official method 975.03. Metal in plants and pet foods, p. 3-4. In: Horwitz, W. and G.W. Latimer (eds.). Official methods of analysis. 18th Ed. AOAC-International, Gaithersburg, MD.

Munns, R. 1993. Physiological processes limiting growth in saline soils: Some dogma and hypotheses. Plant Cell Environ. 16:15-24.

Nelson, D.W. and L.E. Sommers. 1982. Organic matter, p. 574-579. In: Methods of soil analysis Part 2. Chemical and microbiological properties. 2nd Ed. SSSA, Madison, WI.

Neufeld, H., A.H. Chappelka, G.L. Somers, K.O. Burkey, A.W. Davison, and P. Finkelstein. 2006. Visible foliar injury caused by ozone alters the relationship between SPAD meter readings and chlorophyll concentrations in cutleaf coneflower. Photosynth. Res. 87:281-286.
Olsen, S.R., C.V. Cole, F.S. Watanabe, and L.A. Dean. 1954. Estimation of available phosphorus in soils by extraction with sodium bicarbonate. Circular 939. USDA, Washington, DC.

Pieterse, C.M.J., J.A. Van Pelt, B.W.M. Verhagen, J. Ton, S.C.M. VanWees, K.M. Leon-Kloosterziel, and L.C. Van Loon. 2003. Induced systemic resistance by plant growth-promoting rhizobacteria. Symbiosis 35:39-54.

Pirlak, L. and A. Esitken. 2004. Salinity effects on growth, proline and ion accumulation in strawberry plants. Acta Agr. Scand. B 54:189-193.

Rhoades, J.D. 1996. Salinity: Electrical conductivity and total dissolved solids, p. 417-436. In: Methods of soil analysis. Part III. Chemical methods. 2nd Ed. ASA, Madison, WI.

Saleh, S.A., H. Heuberger, and W.H. Schnitzler. 2005. Alleviation of salinity effect on artichoke productivity by Bacillus subtilis FZB24, supplemental $\mathrm{Ca}$ and micronutrients. Appl. Bot. Food Qual. 79:24-32.

Shi, Q., Z. Bao, Z. Zhu, Q. Ying, and Q. Qian. 2006. Effects of different treatments of salicylic acid on heat tolerance, chlorophyll fluorescence, and antioxidant enzyme activity in seedlings of Cucumis sativa L. Plant Growth Regulat. 48:127-135.

SPSS Inc. 2010. SPSS Inc. SPSS ${ }^{\circledR} 18.0$ base user's guide. Prentice Hall.

Thomas, G.W. 1982. Exchangeable cations, p. 159-165. In: Page, A.L., R.H. Miller, and D.R. Keeney (eds.). Methods of soil analysis. Part II. Chemical and microbiological properties, Agronomy Monograph No. 9. 2nd Ed. SSSA, Madison, WI.

Yildirim, E., H. Karlidag, and M. Turan. 2009. Mitigation of salt stress in strawberry by foliar $\mathrm{K}$, Ca and $\mathrm{Mg}$ nutrient supply. Plant Soil Environ. 55:213-221.

Yildirim, E. and A.G. Taylor. 2005. Effect of biological treatments on growth of bean plants under salt stress. Ann. Rept. of Bean Impr. Coop. 48:176-177.

Yildirim, E., A.G. Taylor, and T.D. Spittler. 2006. Ameliorative effects of biological treatments on growth of squash plants under salt stress. Sci. Hort. 111:1-6.

Yildirim, E., M. Turan, and M.F. Donmez. 2008. Mitigation of salt stress in radish (Raphanus Sativus) by plant growth promoting rhizobacteria. Roumanian Biotech. Lett. 13:39333943.

Yildirim, E., M. Turan, M. Ekinci, A. Dursun, and R. Cakmakci. 2011. Plant growth promoting rhizobacteria ameliorate deleterious effect of salt stress on lettuce. Sci. Res. Essays. 6:43894396.

Zhu, J.K., P.M. Hasegawa, and R.A. Bressan. 1997. Molecular aspects of osmotic stress. Crit. Rev. Plant Sci. 16:253-277. 